\title{
Relationship Between Motivation and Organizational \\ Commitment among Scout Volunteers in East Kalimantan
}

\author{
Yeni Rahmawati \\ Faculty of Educational Studies, Universiti Putra Malaysia, Malaysia \\ Norhasni Zainal Abiddin (Correspondence author) \\ Faculty of Educational Studies, Universiti Putra Malaysia, Malaysia \\ E-mail: nonie@upm.edu.my \\ Ihsan Ro'is \\ Faculty of Economic Studies, Universitas Mataram, Indonesia
}

Received: June 26, 2014 Accepted: August 14, 2014 Published: August 16, 2014

doi:10.5296/jsss.v2i1.6151 URL: http://dx.doi.org/10.5296/jsss.v2i1.6151

\begin{abstract}
Numerous studies have been concerned on organizational commitment among profit worker oppositely organizational commitment's studies which focused on nonprofit worker tend to be lack. Nonprofit employee generally recruit and involve volunteer to run their program. Several nonprofit organizations' program is related to non-formal education. For that matter, this study was conducted to evaluate volunteer involvement which especially concern on non-formal education. The objective of this study is to examine relationship between motivation and organizational commitment among volunteer scout as well as find the best predictor affecting organizational commitment. This study used volunteer scout organization since this organization run within non-formal education area. The research used quantitative study to analyze the data. The instrument that has been utilized to collect the data was self administered questionnaire. The data was analyzed descriptively as well as inferentially. The questionnaire was divided into several parts: demographic, Volunteer Function Inventory (VFI), and Organizational commitment (OCQ). The data collection was taken in Samarinda
\end{abstract}


city which located in East Kalimantan-Indonesia. The questionnaire was administered to 207 participants from scout movement center organization. The sample was taken by using random sampling technique and using Scout volunteer in Scout Center-Samarinda as the subject. Finally, the finding of the study revealed that overall motivation as well as the dimension was positively correlated to organizational commitment. Meanwhile, understanding dimension was considered become the best predictor affecting organizational commitment among volunteer scout in East Kalimantan, Indonesia. Several implications were emerged from non-formal education view as well as nonprofit area.

Keywords: Non-formal education, Motivation, Organizational commitment, Scout Volunteer 


\section{Introduction}

According to Okun and Schultz (2003) volunteer is an intentionally action to assist others by ignoring monetary as well as material rewards. Widjaja (2010) reported that there were six elements included volunteerism namely longevity, voluntary action, little no compensation, organizational context and non obligation. Since majority volunteer's goal is concerning as well as giving service to the community development, their action often acknowledged by the public society. In line with this, McCurley and Lynch (2006) also notified that public and nonprofit organization often rely on volunteer to conduct their mission as well as their goal. By this acknowledgment, it can be revealed that the existence of volunteer is certainly helpful and useful for the society. In addition, the volunteer existence is able to provide the need for local societies that are not provided (Ollis, 2001).

In fact, volunteerism cannot be separated with non-formal education (NFE) which certainly becoming an element in extension education. A little farther on, extension education conceptually is meant as stretching out a community who beyond the formal institution. At the first time appear, it was introduced for agricultural and rural education concern. However, the concept of extension education has been adapted in many types education nowadays. Therefore, NFE is appear as general type of extension education whereby both of these term are having similar function and purpose that is activities out of formal restriction and for social development.

As regards to this, NFE are activities built outside the school institution (Merriam and Cafarrella, 1999). Moreover, Digby (2010) notified that NFE can be employed collaboratively with government agencies, environmental learning center or other communities. Meanwhile, volunteer within NFE generally defined as experiences provider as well as mentor who educated the youth such as $4 \mathrm{H}$ (head, heart, hands, and health) activities in United States which concerned on youth development and potential (Terry, Harder and Pracht, 2011) or scouting (Vaske, 2008). Besides from non-formal aspect, this study viewed volunteer from nonprofit organization aspect whereby, it meant as an activity to denote their time without any consideration in term of monetary funding. Moreover, Graff (2006) and Terry et al. (2011) notified that essential resource of nonprofit organization is having volunteer. Volunteer gives benefit for organization in term of cost saving (Allen et al., 1989). By looking at those explanations, it can be enlighten that both of non-formal and nonprofit area has similar purpose that is concern on community service and development rather than pay attention to the financial funding such as in other profit sectors.

Indeed, majority organizational commitment studies have been concerned on compensated employee rather than focused on nonprofit worker (Davila \& Cachon, 2003; Pearce, 1993). Generally volunteering occurs within organizational context. Volunteer need leader to direct their activities to solve the problem rather than improve the society independently (Boyd, 2003). It can be seen that majority volunteer avoid working alone, they choose to join within the organization to develop their work(Chacon, Vecina, \& Davila, 2007). Moreover, they concluded that duration of volunteer service normally can be meant all at once as duration of service in an organization. Thus, between organizational factors would be affected by the 
length of service itself. Otherwise, the services' length is interdependence with the organizational factors.

For that matter, Hartenian (2007) divided two types involvement of the volunteer namely direct and indirect service. Direct service is straightly assisting the community likewise mentoring illiterate person, service for the lonely, helping victim from natural disaster, meanwhile indirect service is a kind of relationship between volunteer and organization under their services. Therefore, besides they provides services and assist the community, indirectly they considered provides their service to the organization. According to Culp (1999) indirect services included manage and coordinate activities and events, senior volunteer who able to teach other volunteer, committee member which able to assist paid staff in planning, evaluating, and implementing the goal of nonprofit and governmental organization. As regards to this matter, a good organizational commitment is required since it completely affecting organizational sustainability in the future and certainly it would influence the length of volunteer service. Therefore, there are two advantages obtained from this relation. Organization needs commitment from their volunteer to run their services, in another side, volunteer needs organization to bond themselves into the services since they avoid working alone. Further, Bang, Ross and Reio (2013) revealed that nonprofit has valuable assets which not possessed in profit organization precisely committed and enthusiastic volunteer. Consequently it can be viewed that commitment is able to determine the viability of nonprofit organization.

According to Meyer and Herscovitch (2001) commitment can be described as energy that ties an individual for relevance achievement to specific goal. Besides organization requires committed employees, organization as well need workforce since it leads to essential result such as reduce the turnover (Phillips \& Edwards, 2008). On the other words, organizational commitment in general context was defined as relationship between organization and individual (Mathieu \& Zajac, 1990). Majority that definition has been utilized in profit area, however, it cannot be denied that there is similar characteristic exist within nonprofit area. Nonprofit organization as well required their employee to have commitment for the organization accordingly. Moreover, as regards to the uniqueness of volunteer characteristic within nonprofit organization, several factor affecting their commitment into their organization was considered varies since they are unpaid and work based on their free time and free choice.

Attitudinal commitment exists when individual and their organization has link each other (Sheldon, 1971). In line with him, Mowday, Steers, and Porter (1979) also emerged commitment in term of attitude. According to their approach, organizational commitment represented attitudinal rather than behavioral approach. Attitudinal commitment signifies individual in terms of identifying a particular organization and its goal and expect to maintain the relationship. Moreover, attitude represented something further than merely simple passive devotion, it requires active participation and action within organization such as offer something to donate into organization. In other words, commitment is not merely from the loyalty which more passive, however, action is required (Dorsch, Riemer, Sluth, \& Paskevich, 2002) whereas in contrast, behavioral commitment intends to shape their environment 
through their behavior rather than reacting to it. However, Meyer and Allen (1997) found the similarity between Mowday's approach and affective commitment which engaged with behavioral. It showed by the strength relative identifies between individual and their involvement within specific organization (Mowday et al., 1979).

Due to the uniqueness of volunteer organization, besides organizational commitment variable, the current study focuses on the motivation among volunteer. Clary et al. (1998) concluded that motivation becoming the important element for volunteer. Motivation can be defined as directing, starting, and maintaining process of physical and emotional activities that involves mechanism in partiality for one activity over another and the energy and perseverance of respond (Gerrig, 2012). Motivation is psychological essential process or a require a behavior activities (Luthans, 2011).

Furthermore, this study refers to six function of motivation from Clary et al. (1998): career, social, value, understanding, enhancement, and protection. Career function refers to individual who participate in a volunteer program to find a career path. Social function is desire to serve according to social factor or it is caused from the normative and social pressure. Value function is showing altruism whereby it represents contribution to the society and to be done for others welfare. Understanding function is individual involvement into the volunteerism merely for opportunity to learn, understand others as well as practice their ability and skill through the services. Enhancement function is serving the community in order to fulfill their self esteem, confidence, and self improvement. Protection function is services in order to reduce their guilty since they feel being wealthier than others. Linked with those functions, functional approach and theory of human need were applied in the current study.

According to functional theory, one individual may have more than one or multiple purpose to involve their self in volunteering. Therefore, this theory permits likelihood of numerous volunteers who engage to equal activity in the association or agency but have different reason from one to the others. Meanwhile, based on human needs theory (Maslow, 1970), there are several hierarchy of need; biological and psychological, safety, belongingness and love, esteem, and self actualization. By adapted this hierarchy, Steers assumed that motivation behavior is influenced by human needs (Steers, 1977).

As aforementioned earlier besides adapted hierarchy of need, this study also utilized functional approach. According to Houle, Sagarin, and Kaplan (2005) recently several studies have used functional strategy to figure out the motives behind volunteerism. It can be seen that functional analysis have been used as the reason and purposes that underlying psychological issue such as social and personal needs, goals, plans, and function being served by people's belief as well as their action (Clary \& Snyder, 1999). Therefore, according to this approach volunteer services may be based on different function although it provides similar attitude and behavior. Further in line with this, Katz (1960) revealed that person may have more than one function for certain attitude or behavior.

In addition, several studies considered support the link between motivation and organizational commitment tend to emerge varies finding. Study in Marion county volunteer 
department found that the motive factors such as understanding and value been affecting organizational commitment of the volunteer (Salas, 2008). Moreover, they found that only three functions which have relationship with organizational commitment namely understanding, value, and protective and enhancement whereby these two last functions were combined. Meanwhile, values factor of volunteer motivation had a important straight impact on affective commitment (Bang et al., 2013). In line with Salas (2008), Siti-Nazilah, Rozmi, and Fauziah (2012) revealed similar finding. According to their study in term of relationship between motivation and organizational commitment under Mowday's Approach (OCQ) found that not overall functional motivation have relationship with organizational commitment. Moreover from six functions offered according to Clary et al. (1998), only four functions which considered had relationship with OCQ namely understanding, altruistic, enhancement, and protection. Further, understanding function was considered has the highest relationship compared others functions namely value, career, social, protection, and enhancement. As comparison, study in profit organization in private sector of Pakistan show the general relationship between work motivation and organizational commitment (Warsi, Fatima, \& Sahibzada, 2009). In sport event volunteer study, it was found that functional motivation predicted the sport volunteer commitment (Sharififar, Jamalian, Nikbakhsh, \& Ramezani, 2011). Moreover, they utilized three-dimension of model (normative, affective, and continuance) under Meyer and Allen (1990). Interestingly, the result notified that there was a linkage between career function with normative commitment.

According to aforementioned explanation, the current study aims generally to examine the relationship between motivation and organizational commitment. Moreover, this study conducted to investigate the best predictor from motivation dimension which affecting organizational commitment. Since this study under non-formal education, the focus subject of the study was scoped for scout volunteer. Consequently, the result might be having different finding with other study in nonprofit areas or other volunteer types.

\section{Materials and Methods}

Since the present study utilized a quantitative research design therefore it used descriptive as well as inferential statistic to analyze the data. Descriptive statistic was notified to describe the demographic of the volunteer while inferential statistic was used to proceed the correlation among the variables The data collection was taken in Indonesia while the target population of the study was scout volunteer who engaged themselves into scout movement organization in East Kalimantan-Indonesia. Considering several limitation, the accessible population that can be involved in the research was only scout volunteer in Scout Center Samarinda-East Kalimantan $(\mathrm{N}=437)$. Simple random sampling technique was used to take the sample. According to Slovin formula the number of sample was 209 respondents.. In order to keep from outlier or other incomplete answer, questionnaire were administered to 220 scouts volunteer. The instrument that was utilized to collect the data was self-administered questionnaire. Moreover, it comprised of three parts namely demographic, volunteer function inventory (VFI) and organizational commitment (OCQ). The pilot study conducted prior before the actual data collection in order to test the reliability per item. 
Meanwhile, six item of demographic questions was adapted from Miller (Miller and Salkind, 2002) while motivation questions was adapted according to six Volunteer Functional Inventory (VFI) from Clary et al. (1998). Moreover, it has 30 item and used 7 point Likert scale ranging 1 (extremely not important) to 7 (extremely important). Finally, organizational commitment (OCQ) was adapted from Mowday et al. (1979). However, after the pilot study done priory, only 12 items of OCQ could be processed. Moreover, this variable was considered as uni-dimensional variable. It was using 7 point Likert scale ranging from 1 for extremely disagrees to 7 for extremely agree. Therefore the total item of the questionnaire included the demographic was 48 items. Meanwhile, Cronbach alpha for overall variables was reaching >.70; career and understanding (.72), social and enhancement (.71), value (.76), protective (.75), overall motivation (.91), and organizational commitment (.77).

\section{Results and Discussions}

However, only 94\% samples $(n=207)$ can be processed for real data collection otherwise 13 samples was considered as incomplete. According to the descriptive statistic, majority were male volunteer $(60.9 \%)$ rather than female volunteer $(39.1 \%)$, the largest part of them were in 21 to 25 years old (41\%) and only few volunteer in 41 to 47 years old $(0.5 \%)$, commonly single $(52.7 \%)$ while one percent were divorced. Based on education, majority volunteer were in undergraduate level (41.1\%), little number from post graduate $(6.8 \%)$, a number of volunteer have $\leq 1$ year length involvement in scout volunteer $(34.3 \%)$ whereas $\geq 10$ years length involvement fulfilled by only 5 volunteer $(2.4 \%)$. They involved themselves into volunteering activity in every 4 times in a month $(48.3 \%)$ while more than 4 times involvement in a month considered rare (15\%).

Further, the correlation coefficient between motivation and organizational commitment was examined as inferential statistic. The exploratory data analysis was treated to observe whether the data was normal or not normal. Considering overall the data were normal, parametric statistic should be employed. Therefore Pearson Correlation was being selected to ensure the relationship among variables. Moreover, the result of the data collection indicated that there was a moderate positive correlation between overall motivation and organizational commitment $(\mathrm{r}=.468, \mathrm{p}<.05)$ thus the null hypothesis was rejected (see Table 1$)$. The data further analyzed for each dimension of motivation accordingly. As a result (see Table 1), there was positive correlation between career and organizational commitment $(r=.429$, $\mathrm{p}<.05)$, social and organizational commitment $(\mathrm{r}=.362, \mathrm{p}<.05)$, value and organizational commitment $(\mathrm{r}=.419, \mathrm{p}<.05)$, understanding and organizational commitment $(\mathrm{r}=.436$, $\mathrm{p}<.05)$, enhancement and organizational commitment $(\mathrm{r}=.268, \mathrm{p}<.05)$, protection and organizational commitment $(\mathrm{r}=.321, \mathrm{p}<.05)$. According to the result, these positive correlations indicated that scout volunteer who has more motivation also have more committed to the organization. However, the results have weak significant correlation among overall motivation as well as the dimension although majority all of them have positive significant relationship.

The finding was steady with previous studies among volunteer in several fields. According to the research in public universities Peninsular Malaysia $(n=350)$, understanding function $(r$ 


\section{Macrothink}

$=.317, \mathrm{p}<.05)$ has higher relationship with organization commitment among student college volunteer compared with other function (Siti-Nazilah et al., 2012). Moreover, similar result also showed by Salas (2008) through his study in Marion County government volunteer which placed in Ocala, Florida. The finding reported that understanding and values were significant explanatory variables of organizational commitment from the response rate reached $89 \%(n=229)$ volunteer. Further, Bang et al., (2013) reported that values function had significant on affective commitment in nonprofit sport organization $(\mathrm{n}=214)$. Meanwhile, the research was taken in 22 nonprofit sport organizations Midwestern-USA.

Table 1. Pearson correlation product moment correlations

\begin{tabular}{lll}
\hline Variables & $\mathrm{R}$ & $\mathrm{P}$ \\
\hline Career & $.429^{* *}$ & .00 \\
Social & $.362^{* *}$ & .00 \\
Value & $.419^{* *}$ & .00 \\
Understanding & $.436^{* *}$ & .00 \\
Enhancement & $.268^{* *}$ & .00 \\
Protection & $.321^{* *}$ & .00 \\
Overall motivation & $.468^{* *}$ & .00 \\
\hline
\end{tabular}

** Correlation is significant at the .01 level ( 2 tailed).

The finding also indicated that understanding function considered as the best predictor affected organizational commitment (see Table 2). However, based on the finding, it reported that not overall data support the predictor of multiple regression models. Variable dimension with a high beta coefficient were highly essential in contributing the criterion variable. According to the beta value obtained, the beta coefficient for understanding was .217 otherwise other dimensions resulted coefficient below than it. It means that understanding has a higher power than other dimension in predicting organizational commitment. Meanwhile, according to $\mathrm{F}$ statistic $(\mathrm{F}=10.875, \mathrm{p}<.05)$ the model was fit the data. 
Table 2. Multiple regression analysis

\begin{tabular}{lllllllll}
\hline Model & \multicolumn{2}{l}{$\begin{array}{l}\text { Unstandardized } \\
\text { Coefficients }\end{array}$} & $\begin{array}{l}\text { Standardized } \\
\text { Coefficients }\end{array}$ & $\mathrm{t}$ & Sig. & correlations & \\
& $\mathrm{B}$ & Std. Error & Beta & & & Zero-order & Partial & part \\
\hline (Constant) & 36.926 & 36.926 & & 10.831 & .000 & & & \\
Career & .287 & .154 & .180 & 1.862 & .064 & .429 & .131 & .114 \\
Social & .108 & .138 & .066 & .779 & .437 & .362 & .055 & .048 \\
Value & .135 & .148 & .091 & .910 & .364 & .419 & .064 & .056 \\
Understanding & .392 & .155 & .217 & 2.526 & .012 & .436 & .176 & .155 \\
Enhancement & -.022 & .113 & -.016 & -.195 & .846 & .268 & -.014 & -.012 \\
Protection & .073 & .122 & .051 & .600 & .549 & .321 & .042 & .037 \\
Summary Regression & & & & & & & \\
Multiple $R$ & & .496 & & & & & & \\
$R$ square & .246 & & & & & & & \\
Adjusted $R$ Square & .223 & & & & & & & \\
$F$-statistics & 10.875 & & & & & & & \\
\hline
\end{tabular}

In addition, in term of motivation, theory of Maslow and functional theory contributed the current study. On the other hand, it indicated that the needs of career, social, value, understanding, enhancement, and protection motives were salient as well as important for organizational commitment among scout volunteer. Moreover, understanding motive was considered as the major influential motive, therefore through this study, it supposed that scout volunteer indirectly more feeling appraise about others and gain the new perspectives on things by learning new experience, skill, and self potential (Clary et al., 1998). Therefore, these advantages were able to provide the influence regarding their commitment within organization. However, this study ascertains the moderate level of relationship of variables in term of motivation. This condition possibly explained that generally motivation was not strongly become important part for organizational commitment (Siti-Nazilah et al., 2012). Scout volunteer were able to fulfill their needs and involvement without compulsory having a bunch of emotionally with organization.

\section{Conclusion}

The current study has theoretical importance and similar previous studies that supported the finding under hierarchy of need (Maslow, 1970) which addressed on the existence of humans needs. In this study, generally motivation was considered as a need that must be accomplished by scout volunteer to engage them into organization and to maintain their commitment to the organization. Whereas from functional theory, it was indicated that different functions may serve similar attitude or behavior. Moreover, individual may have more than one function to show their attitude or behavior. In other words, an individual may have more than one need to employ themselves into particular organization. However, there were several limitations. Since the data were collected from a specific volunteer organization which tends to be referred for non-formal learning or extension education area, thus the 
generalization of the finding was limited. Therefore, it requires to be enlarged for other sources included.

However, the finding of this study contributed to the knowledge especially for extension education which has non-formal learning system. Practically through this study, it permitted scout volunteer and stakeholder from two aspect non-formal education as well as nonprofit organization to comprehend the situation according to the finding especially scouts movement organization in Scout center-Samarinda. It is important for them to be familiar and realize with their personal factors of motivation whether they involve themselves due to career, social, value, understanding, enhancement or protection function. Finally, by recognizing all those dimensions, scout volunteer would be able to improve their organizational commitment although previous study found that it was no need to have strong motivation to get organizational commitment (Siti-Nazilah et al., 2012). Stakeholders have to provide their attention to establish the system and programs, as well as provide a good training and managing to increase organizational commitment from the volunteer. Therefore, it is expected that those efforts would possibly affect their long services to the program. In addition, this study contribute to NFE or extension education area since by improving scout organization with various systems and management, indirectly it provide improvement for out of school program. Therefore, it provides contribution to the informal as well as NFE especially for youth development community. For future research, the instrument utilized to measure organizational commitment in the current study was more general to overall types of organizational commitment. Therefore, there was no specification either for unpaid worker or another part of worker. Further study should be confirmed to specific component of organizational commitment to meet relationship especially for volunteer. Future research also suggested to more concern on organizational commitment which involve volunteer who run another NFE program such as illiteracy program or education for unreached children that cannot reaching formal education.

\section{References}

Allen, J., Chi, K., Davlin, K., Gall, M., Hatry, H., \& Masterman, W. (1989). The private sector in state service delivery: Examples of innovative practices. Washington, D. C: Urban Institute Press.

Bang, H., Ross, S., \& Reio, T. G. (2013). From motivation to organizational commitment of volunteers in non-profit sport organizations: The role of job satisfaction. Journal of Development Management, 32(1), 96-112.

Boyd, B. L. (2003). Identifying copetences for volunteer administration for the coming decade: A Delphi study. Journal of Agricultural Education, 44(4), 47-56. http://dx.doi.org/10.5032/jae.2003.04047

Chacon, F., Vecina, M. L., \& Davila, M. C. (2007). The Three-Stage Model of Volunteers ' Duration of Service. Social Behavior and Personality, 35(5), 627-642. http://dx.doi.org/10.2224/sbp.2007.35.5.627

Clary, E. G., Snyder, M., Ridge, R. D., Copeland, J., Stukas, A. A., Haugen, J., \& Miene, P. 
(1998). Understanding and assessing the motivations of volunteers: a functional approach. Journal of Personality and Social Psychology, 74(6), 1516-1530. http://dx.doi.org/10.1037/0022-3514.74.6.1516

Davila, M. C. L., \& Cachon, F. (2003). Adaptation de instrumentos para la evaluacion de aspectos organizacionales en ONG's in Davila et al. (2010). Organizational commitment in Spanish and italian Volunteers: A comparative study. Revista de Psicologia Del Trabajo Y de Las Organizaciones, 19(2), 159-179.

Digby, C. L. B. (2010). An Examination of the Impact of Non-formal and Informal Learning on Adult Environmental Knowledge, Attitudes, and Behaviors. The University of Minnesota. Proquest.

Dorsch, K. D., Riemer, H. A., Sluth, V., \& Paskevich, D. M. (2002). What Affects A Volunter's Commitment? What Affects a Volunteer 's Commitment? Canadian Centre for Phylanthropy, 1-8.

Gerrig, R. J. (2012). Psychology and Life, 20/E. Pearson. Stony Brook University: Pearson, Cloth. p. 624.

Hartenian, L. S. (2007). Nonprofit agency dependence on direct service and indirect support volunteers: An empirical investigation. Nonprofit Management and Leadership, 17(3), 319-334. http://dx.doi.org/10.1002/nml.152

Houle, B. J., Sagarin, B. J., \& Kaplan, M. F. (2005). A Functional Approach to Volunteerism: Do Volunteer Motives Predict Task Preference? Basic and Applied Social Psychology, 27(4), 337-344. http://dx.doi.org/10.1207/s15324834basp2704_6

Luthans, F. (2011). Organizational Behavior (3rd ed.). New York: McGraw-Hill. p. 574. http://dx.doi.org/10.1080/01608061.2011.619421

Maslow, A. H. (1954). Motivation and personality. New York: Harper. http://dx.doi.org/10.1111/j.1467-6494.1954.tb01136.x

Mathieu, J. E., \& Zajac, D. M. (1990). A review and meta-analysis of the antecedents, correlates, and consequences of organizational commitment. Psychological Bulletin, 108(2), 171-194. http://dx.doi.org/10.1037/0033-2909.108.2.171

McCurley, S., \& Lynch, R. (2006). Volunteer management: Mobilizing all the resources of the community (2nd ed.). Kemptville: ON: Johnstone Training and Consultation, Inc.

Merriam, S. B., \& Cafarrella, R. S. (1999). Learning in Adulthood (2nd ed.). San Fransisco: Jossey-Bass.

Meyer, J. P., \& Herscovitch, L. (2001). Commitment in the workplace: toward a general model. Human Resource Management Review, 11(3), 299-326. http://dx.doi.org/10.1016/S1053-4822(00)00053-X

Miller, D. C., \& Salkind, N. J. (2002). Handbook of Research Design and Social Measurement. London: Thousand Oaks: Sage Publication. 
Mowday, R. T., Steers, R. M., \& Porter, L. W. (1979). The measurement of organizational commitment. Journal of Vocational Behavior, 14(2), 224-247. http://dx.doi.org/10.1016/0001-8791(79)90072-1

Okun, M. A., \& Schultz, A. (2003). Age and motives for volunteering: testing hypotheses derived from socioemotional selectivity theory. Psychology and Aging., 18(2), 231-239. http://dx.doi.org/10.1037/0882-7974.18.2.231

Ollis, T. (2001). Volunteers, ideology and pratice towards a new century of volunteerism. Ethos, 9(2), 11-17.

Pearce, J. L. (1993). Volunteers: The organizational behaviour of unpaid workers. London/New York: Routledge.

Phillips, J. J., \& Edwards, L. (2008). Managing Talent Retention: an ROI Approach (1st ed). San Fransisco, USA: Pfeiffer. p. 432

Ryan, R. L., Kaplan, R., \& Grese, R. E. (2001). Predicting Volunteer Commitment in Environmental Stewardship Programmes. Journal of Environmental Planning and Management, 44(5), 629-648. http://dx.doi.org/10.1080/09640560120079948

Salas, G. R. (2008). Volunteer functions, satisfaction, commitment, and intention to leave government volunteering.

Sharififar, F., Jamalian, Z., Nikbakhsh, R., \& Ramezani, Z. N. (2011). Influence of Social Factors and Motives on Commitment of Sport Events Volunteers. World Academy of Science, Engineering and Technology, 53, 5-20.

Sheldon, M. E. (1971). Investments and Involvements as Mechanisms Producing Commitment to the Organization. Administrative Science Quarterly, 16(2), 143-150. http://dx.doi.org/10.2307/2391824

Siti-Nazilah, M. A., Rozmi, I., \& Fauziah, I. (2012). Relationship Between Motivation and Organizational Commitment among College Student Volunteers.pdf. International Business Management Medwell Journal, 6(4), 512-516.

Steers, R. M. (1977). Antecedents and Out- comes of Organiza- tional Commitment. Administrative Science Quarterly, 22(1), 46-56. http://dx.doi.org/10.2307/2391745

Terry, B., Harder, A., \& Pracht, D. (2011). Understanding the Value of Volunteer Involvement. Journal of Agricultural Education, 52(2), 118-127. http://dx.doi.org/10.5032/jae.2011.02118

Vaske, A. (2008). The relationship between motivation to volunteer and cultural preference: A study of a youth developemnt organization. Proquest Database. St. Ambrose University.

Warsi, S., Fatima, N., \& Sahibzada, S. A. (2009). Study on Relationship Between Organizational Commitment and its Determinants among Private Sector Employees of. International Review of Business Research Papers, 5(3), 399-410.

Widjaja, E. (2010). Motivation Behind Volunteerism. Claremont McKenna College. 


\section{Copyright Disclaimer}

Copyright reserved by the author(s).

This article is an open-access article distributed under the terms and conditions of the Creative Commons Attribution license (http://creativecommons.org/licenses/by/3.0/). 